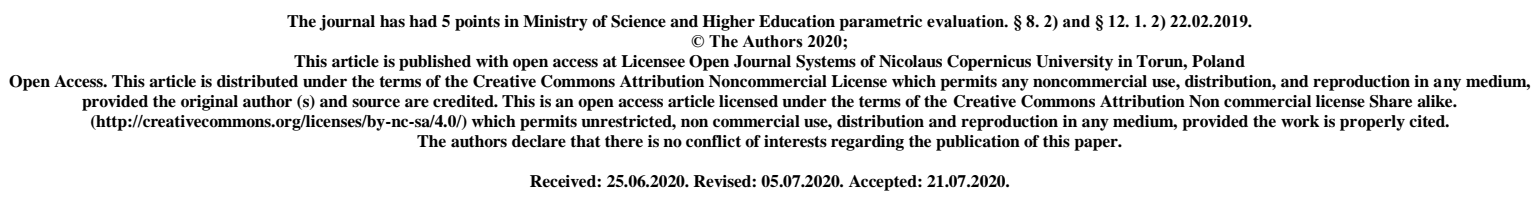

\title{
Insulin resistance: from the source of development to clinical consequences
}

\author{
Waldemar Pluta, Wioleta Dudzińska, Anna Lubkowska \\ Department of Functional Diagnostics and Physical Medicine, Pomeranian Medical \\ University in Szczecin, Żołnierska 54 Str., 71-210 Szczecin, Poland
}

\begin{abstract}
Insulin resistance is a disorder of glucose homeostasis, which is a decrease in tissue sensitivity to insulin despite normal or elevated serum hormone levels. The main sources of development are genetic and environmental factors, including excessive consumption of fats, simple sugars and high-calorie foods, and lack of physical activity. One of the most objective methods of assessing insulin resistance is the HOMA-IR index calculated on the basis of glucose and insulin levels in the blood. Among the clinical consequences, type 2 diabetes and polycystic ovary syndrome play the most important role. The goal of treatment is not only to reduce insulin resistance, but also to protect pancreatic $\beta$ cells.
\end{abstract}

KEY WORDS: insulin resistance, type 2 diabetes, polycystic ovary syndrome 


\section{INTRODUCTION AND PURPOSE}

Insulin resistance is a disorder of glucose homeostasis, which is a decrease in tissue sensitivity to insulin despite normal or elevated serum hormone levels. Because glucose is an essential element for cell survival, the body balances insulin resistance by producing more insulin [1, 2]. Insulin resistance causes metabolic disorders in various tissues [3]. The most serious clinical sequelae include type 2 diabetes, metabolic syndrome and polycystic ovary syndrome $[1,4]$. The main sources of insulin resistance development are genetic and environmental factors, including excessive consumption of fats, simple sugars and high-calorie foods, and lack of physical activity [5-8]. There are many methods for assessing insulin resistance. One of the most objective methods is the HOMA-IR index calculated on the basis of blood glucose and insulin levels [4]. In order to fully understand glucose homeostasis disorder, it is necessary to know the role of adipose tissue in its pathogenesis [9].

The purpose of this study was to characterize the phenomenon of insulin resistance. The work deals with the mechanisms, sources of development, assessment methods as well as clinical consequences and the possibilities of their treatment. Our research material consisted of publications that were found in the PubMed, ResearchGate and Google Scholar databases. To find relevant publications, the search was performed using a combination of keywords such as "insulin resistance", "insulin resistance syndrome", "metabolic syndrome", "cardiovascular disease". The first step was to find relevant publications from the last 10 years. The second step was to review the publications found.

\section{DESCRIPTION OF THE STATE OF KNOWLEDGE Definition}

Insulin resistance is defined as a disorder of glucose homeostasis, it is characterized by reduced tissue sensitivity to insulin despite normal or elevated serum levels of this hormone. Because glucose is an essential energy substrate for cells, the body balances insulin resistance by producing more insulin. The result is an excess hormone in the blood (hyperinsulinemia) and excessive stimulation of tissues that are still sensitive to the effects of insulin. The consequences of this process are imbalances between insulin and glucose, followed by disorders of carbohydrate, protein and lipid metabolism resulting in a significant increase in the amount of triglycerides and LDL cholesterol in the blood, while reducing the HDL fraction. This in turn raises the risk of thrombosis or other inflammatory changes, including sodium retention, resulting in increased blood pressure $[2,10,11]$.

\section{Types of insulin resistance}

There are three mechanisms of disorders leading to resistance to this hormone - pre-receptor, receptor and post-receptor insulin resistance.

Pre-receptor resistance may be caused by: abnormal structure of insulin molecules ("mutant insulin syndrome"), increased hormone degradation, the presence of antibodies in the blood that bind normal insulin molecules or antagonist hormones, e.g. glucagon, growth hormone, androgens, cortisol and thyroid hormones.

Receptor resistance is most often caused by a decrease in the number of insulin receptors or their hormone affinity. In addition, a change in insulin receptor structure or function may result from mutations. 
Post-receptor resistance is most often associated with disorders in the processes of signaling the attachment of the hormone to its receptor. Often, there are also irregularities in the structure and functioning of glucose transporters inside the cell. Resistance may also be associated with increased lipolysis, which results in an increase in the amount of FFA. Its excessive oxidation is responsible for inhibiting lipolysis.

Insulin resistance may be a consequence of disturbances in insulin receptor structure or function. Receptors are glycoproteins consisting of two $\alpha$ subunits and two $\beta$ subunits and are located on the surface of all body cells, most of them are on the surface of hepatocytes and adipocytes.

The development of insulin resistance may be due to abnormal work and the number of insulin receptors, as well as a decrease in the reactivity of target cells, resulting in excessive stimulation of insulin, which is a consequence of improper work of the pancreatic B cells. The proper functioning of insulin receptors may be impaired due to the presence of antibodies directed against these receptors in the blood [1].

Insulin resistance may have a hepatic and a peripheral form. The hepatic form affects hepatocytes and causes uncontrolled intensification of hepatic glycogenolysis and gluconeogenesis as well as the production of VLDL cholesterol and triglycerides. On the other hand, the peripheral form develops in adipose tissue and skeletal muscles, and is manifested by impaired glucose uptake and utilization by skeletal muscles and increased lipolysis in adipose tissue, which results in increased release of free fatty acids $[12,13]$.

Tabela 1. Mechanisms of insulin resistance [12]

\begin{tabular}{|c|c|c|}
\hline Pre-receptor & Receptor & Post-receptor \\
\hline $\begin{array}{c}\text { Genetically conditioned } \\
\text { abnormal structure of } \\
\text { insulin molecules (so- } \\
\text { called mutated insulin } \\
\text { syndrome) }\end{array}$ & $\begin{array}{c}\text { Decrease in the number of } \\
\text { insulin receptors }\end{array}$ & $\begin{array}{c}\text { Disorders in processes signaling the } \\
\text { attachment of insulin to the insulin } \\
\text { receptor (disorders in intracellular signal } \\
\text { transmission) }\end{array}$ \\
$\begin{array}{c}\text { Increased insulin } \\
\text { degradation }\end{array}$ & $\begin{array}{c}\text { Decreased insulin receptor } \\
\text { affinity (mutations) }\end{array}$ & $\begin{array}{c}\text { Irregularities in the structure and operation } \\
\text { of glucose transporters inside the cell }\end{array}$ \\
$\begin{array}{c}\text { Blood antibodies that bind } \\
\text { normal insulin (IgG) } \\
\text { molecules }\end{array}$ & $\begin{array}{c}\text { Increased lipolysis - the number of free } \\
\text { fatty acids increases, and their excessive } \\
\text { oxidation is responsible for inhibiting } \\
\text { glycolysis }\end{array}$ \\
$\begin{array}{c}\text { Presence in the blood of } \\
\text { substances or hormones } \\
\text { with insulin antagonism: } \\
\text { cortisol, glucagon, growth } \\
\text { hormone, thyroid } \\
\text { hormones }\end{array}$ & \\
\end{tabular}




\section{Sources of development}

Genetic and environmental factors are the main sources of the development of insulin resistance. Studies have confirmed the effect of polymorphism of many genes whose transcription affects insulin secretion and is associated with the development of obesity, e.g. mutation of the TCF7L2 gene. In the case of environmental factors, excessive consumption of simple sugars, fats, high-calorie foods and lack of physical activity have the greatest impact on the development of the disease. These disorders can occur under the influence of drugs such as corticosteroids, thiazides, under the influence of various toxins and as a result of metabolic stress caused by infection or stress. Factors that increase the risk of insulin resistance are also acquired diseases, including those from the group of diseases called civilization (diabetes, thyroid disease, polycystic ovary syndrome). Most cases of insulin resistance are due to the interaction of some or all of these factors. Scientists, in the case of the impact of obesity on the development of insulin resistance, pay most attention to the socalled male type of obesity, or abdominal obesity. Excessive growth of visceral fat results in the formation of permanent inflammatory reactions, which is a consequence of excessive secretion, among others resistins and TNF $\alpha$. Secreted compounds cause interference in the transmission of information to insulin-sensitive receptors [5-8]. In the case of insulin resistance of adipose tissue, the inhibitory effect of insulin on the lipolysis process is reduced, which results in increased circulating FFA. Their elevated concentration inhibits glucose uptake in other tissues, e.g. in muscles. In addition, GLUT4 translocation is impaired and glucose transport to cells is reduced [14].

\section{Methods of direct assessment of insulin resistance}

\section{Metabolic clamp method}

It is characterized by accuracy and repeatability of results. It is considered the "gold standard" in the determination of insulin resistance. The principle of the method is to determine the amount of glucose that must be administered to the patient to maintain a stable glucose value during the 2 hour insulin infusion. The glucose consumption limit is $8 \mathrm{mg} / \mathrm{min} / \mathrm{kg}$ FFM. Values above $8 \mathrm{mg} / \mathrm{min} / \mathrm{kg}$ FFM are considered normal, whereas values below $8 \mathrm{mg} / \mathrm{min} /$ kg FFM indicate impaired insulin sensitivity. This is the most commonly used method, but it is quite technically difficult, time-consuming and cost-intensive.

\section{Insulin tolerance test}

A method for assessing insulin sensitivity based on response to a given (exogenous) hormone. If insulin secretion hormone secretion disorders occur and people with diabetes complicated by peripheral neuropathy can be expected to have increased sensitivity to administered insulin, the test carries a risk of hypoglycemia, therefore it is recommended to perform it after a preliminary assessment of insulin sensitivity. 


\section{Endogenous suppression test}

This study involves blocking the secretion of endogenous insulin by administering propranolol and adrenaline. Tests showed elevated glucose values in people with insulin resistance, while people with normal insulin sensitivity obtained these values in the normal range. When performing the test, keep in mind that high glucose results may be distorted due to renal glucose excretion, and that conduction and arrhythmia may occur during the test. Complications can be avoided by using somatostatin to block endogenous insulin secretion.

\section{Methods of indirect assessment of insulin resistance}

1. The insulinemia / glycemia ratio

Calculated as the quotient of insulin concentration (IU / l) and blood glucose (mg / dL). A value above 0.3 indicates insulin resistance. The advantage of this test is that it can be used both under basal conditions (on an empty stomach) and during an oral glucose tolerance test. The limitation on the use of this method is the endogenous insulin secretion disorder [1].

\section{HOMA-IR indicator}

The insulin resistance coefficient is calculated on the basis of glucose and insulin levels in the blood according to the following formula:

$$
\begin{gathered}
\text { HOMA }-I R\left(\frac{m m o l}{L} \times \mu \frac{U}{m l}\right)= \\
\frac{\text { fasting glucose }\left(\frac{m m o l}{L}\right) \times \text { fasting insulin }(\mu U / m l)}{22,5}
\end{gathered}
$$

Under physiological conditions, this factor is below 1.0. Values above this norm indicate peripheral insulin resistance or hepatic origin $[4,13]$.

\section{QUICKI indicator}

The indicator is calculated from the formula:

$$
1 / \text { (fasting insulin } \log (\mu \mathrm{U} / \mathrm{ml})+\text { fasting blood glucose }(\mathrm{mmol} / \mathrm{l}))
$$

Insulin resistance is indicated by the value $<0.34$

\section{Matsuda indicator}

The indicator is calculated from the formula:

100,000 / insulin fasting $(\mathrm{mU} / \mathrm{ml}) \mathrm{x}$ fasting glucose $(\mathrm{mg} / \mathrm{dl}) \mathrm{x}$ mean glucose in the oral glucose test (OGTT) $\mathrm{x}$ mean insulin in OGTT

Insulin resistance is indicated by the value $<7.3$. 


\section{Intravenous glucose tolerance test}

This study consists of determining the tissue glucose assimilation factor $\mathrm{K}$, which expresses the percentage of glucose that will disappear within 1 minute from the extracellular space. The test consists of administering glucose at a dose of $0.33 \mathrm{~g} / \mathrm{kg}$. for rapid infusion and glucose measurement: before the start of the test and every 10 minutes in the first hour of the test.

In people with normal glucose tolerance, the $\mathrm{K}$ value is $1.5-2.5$. A value $<1.5$ with simultaneous normal or elevated plasma insulin levels suggests insulin resistance.

\section{Double intravenous glucose test}

This test also includes determining the tissue assimilation factor $\mathrm{K}$; glucose is administered intravenously at a dose of $0.33 \mathrm{~g} / \mathrm{kg}$. In addition, glucose is repeated at the same dose together with insulin $(0.1 \mathrm{U} / \mathrm{kg})$. The difference between $\mathrm{K}$ values provides information on the effect of exogenous insulin.

\section{Bergman's method}

This method is based on intravenous administration of glucose to the test person in a dose of $0.3 \mathrm{~g} / \mathrm{kg}$. After 20 minutes, tolbutamide is administered intravenously, which stimulates the secretion of endogenous insulin. The dose of tolbutamide is adjusted for body mass index. Within 3 hours of the test, 26 insulin and venous glucose tests are performed. The results obtained and the mathematical model proposed by Bergman allow the determination of the tissue sensitivity coefficient for insulin $[1,8,15-18]$.

\section{The effect of insulin resistance on the body}

Insulin resistance causes metabolic disorders in various tissues. It reduces the uptake and consumption of glucose in the oxidation process and impairs its storage in the form of glycogen in skeletal muscle. In the case of adipose tissue, no inhibitory effect on lipolysis was observed, in the case of the liver, insulin impairment reduced the inhibition of hepatic glucose production. Insulin resistance is a major pathogenetic factor of type 2 diabetes. The decrease in tissue sensitivity to insulin is compensated by hyperinsulinemia, which means that some people with insulin resistance do not develop type 2 diabetes for many years. However, these people have other components of the metabolic syndrome, namely hypertension, abdominal obesity, atherogenic dyslipidemia, i.e. hypertriglyceridemia, low cholesterol of high density lipoprotein fraction and the presence of small, dense lipoprotein particles. Insulin resistance and the closely related obesity are associated with a chronic inflammatory response with low activity in various tissues [3]. Insulin resistance contributes to the development of hypotriglyceridemia, excessive production of very low density b lipoproteins, low density lipoproteins, accelerated catabolism of high density lipoproteins and reduction of HDL receptor activity. The developing decrease in peripheral tissue sensitivity to insulin, together with the increased lipotic activity of adipose tissue affects the increase of insulin resistance and promotes the development of cardiovascular disorders. In addition, increased peripheral tissue resistance to insulin adversely affects the function of the vascular wall. Insulin resistance increases the accumulation of visceral fat, which is a source of acute phase 
proteins, proinflammatory cytokines, and thrombotic factors, predisposes to vasospasm, promoting the development of hypertension. Insulin resistance is accompanied by increasing lipotoxicity, which is the result of prolonged exposure of pancreatic $\beta$ cells, smooth muscle cells and endothelium to very low density lipoproteins, circulating free fatty acids, compounds with cytotoxic properties, e.g. ceramide, diacylglycerol and triglycerides. Increased lipolysis in adipose tissue along with the increase in the concentration of free fatty acids intensify the processes of fatty acid oxidation and reduction of glycolysis, as a result of which the activity of glycogen synthesis and functions dependent on GLUT4 glucotransporters are slowed down. The increase in fatty acid in the liver minimizes insulin degradation, resulting in increased hyperinsulinemia and insulin sensitivity. The consequence of obesity is an increase in leptin concentration, which contributes to the further development of insulin resistance.

Increasing hyperinsulinemia leads to a decrease in the number of receptors in peripheral tissues. The sensitivity of insulin receptors to the hormone decreases under the influence of tumor necrosis factor $\alpha$. An important role in the development of insulin resistance and the formation of obesity is transcriptional receptor dysfunction. Insulin activation of peroxisome proliferators has an impact on the increase of insulin sensitivity and limit the expression of GLUT glucotransporters. Insulin resistance also develops under the influence of $\beta 3$ adrenergic receptor dysfunction in adipose tissue and increased production of inflammatory mediators, which in turn affects the activation of the NF- $x \mathrm{~B}$ transcription factor pathway in the liver and adipose tissue [5, 19].

\section{Clinical consequences of insulin resistance \\ Type 2 diabetes}

The conducted research allows to state that the decrease in insulin sensitivity is detectable many years before the diagnosis of type 2 diabetes [20, 21]. The basic pathogenetic mechanisms in the development of type 2 diabetes are insulin resistance and pancreatic $\beta$-cell secretory dysfunction $[1,22]$. The blood glucose level is kept within the reference range as long as the $\beta$-cell compensatory mechanism is efficient. This results in the fact that many people with known severe insulin resistance do not develop diabetes. However, these people are still at high risk of developing premature atherosclerosis, comparable to those at type 2 diabetes [23]. Already in the early stages of the disease, some of the more subtle functional tests reveal the deterioration of certain $\beta$-cell functions [24]. As a result, the increasing $\beta$ cell defect results in hyperglycemia. In patients with type 2 diabetes, impaired insulin secretion is not inhibited, while hormone resistance stabilizes at full-blown diabetes, as demonstrated in studies [25]. In the development of type 2 diabetes, the first phase of insulin secretion is very early. The later phase is characterized by reduced and delayed hormone secretion in response to oral load. The advanced phase, which lasts for many years, is characterized by a very low level of insulin secretion. It is worth mentioning that in the course of the disease a decrease in the percentage of insulin content in the cell secretory product in favor of proinsulin and a reduction in the function of the incretin axis are observed. Studies in animal models and patients' autopsies have shown a 30-50\% reduction in $\beta$ cells and an accumulation of amyloid deposits in islets [26]. However, this does not explain the intensification of the defect [23]. 


\section{Polycystic ovary syndrome (PCOS)}

Polycystic ovary syndrome (PCOS) is one of the most common endocrine disorders affecting $10-15 \%$ of women of childbearing age. The etiology of the disease is still not fully understood, and the clinical picture is extremely variable, but generally includes clinical or biochemical hyperandrogenism, menstrual disorders and polycystic ovaries on ultrasound [18]. Studies in the 1980s have provided information that insulin resistance and elevated insulin levels may be an essential element in the pathogenesis of PCOS [27, 28]. It turned out that about $50 \%$ of women with PCOS also suffer from insulin-related disorders, with a significant proportion (70\%) being obese [29]. The effects of elevated insulin concentration on the ovaries include, among others: increased expression of $3 \beta-\mathrm{OH}$ steroid dehydrogenase in ovarian granular cells, increased response to gonadotropins or an increase in 17hydroxylase and 17-20-lyase activity [1, 4]. Elevated insulin levels can lead to increased testosterone production in the ovaries, which can result in, among others, the development of ovarian cysts, menstrual disorders or excessive hair growth [30]. An in vitro experiment on skin fibroblasts gave insight into the cellular and molecular mechanisms of insulin action in PCOS [31]. Other in vitro studies, this time on adipocytes and skeletal muscle, have shown an increase in subcutaneous adipocytes in both slim and obese women with PCOS. The number of insulin adipocyte receptors or their affinity in PCOS patients was similar to control [32] however, a reduced number of insulin receptor beta subunits in visceral fat in women with syndrome [33].

\section{Metabolic syndrome}

Reduced insulin sensitivity is considered to be one of the major pathogenetic factors of metabolic syndrome. It is important because the alternative name for the metabolic syndrome is "insulin resistance syndrome" [34]. The prevalence of the disorder increases with age, in people over 60 years old is about $40 \%$. MetS significantly increases the risk of developing coronary heart disease. Other consequences include: thrombophilia, endothelial dysfunction, decreased adiponectin A1, fatty liver, inflammation, increased uric acid, leptin, fibrinogen, LDL-C and increased alanine aminotransferase [35]. Genetic and environmental factors play an important role in the pathogenesis of the metabolic syndrome. The conducted genetic studies have proved the importance of gene polymorphisms associated with PPAR $\gamma$ nuclear receptors, including increasing insulin sensitivity and regulating adipogenesis [36]. Other genes include the resistin gene and the calpain 10 gene. Environmental factors include physical inactivity and poor nutrition resulting in overweight and obesity. Obesity and overweight, in particular its visceral type, lead to insulin resistance and compulsive hyperinsulinemia [4].

\section{Cardiovascular diseases (CVD)}

Correlation between insulin resistance and the occurrence of coronary artery disease, atherosclerosis and cardiovascular mortality has been demonstrated in many studies [37-43]. The first study was The Insulin Resistance Atherosclerosis Study (IRAS), which aimed to assess the relationship between insulin sensitivity and atherosclerosis based on ultrasound thickness measurement of the intima-media carotid complex. A higher insulin sensitivity index has been shown to be negatively correlated with atherosclerosis. This effect is partly 
dependent on classic cardiovascular risk factors. There was no statistically significant relationship between insulin sensitivity and IMT in black people [44]. In turn, the Helsinki Policemen Study observational study, which lasted 22 years, showed a correlation between insulin resistance and the occurrence of coronary heart disease [45]. Després et al. [46]confirmed that hyperinsulinemia is an independent risk factor for coronary heart disease. In turn, the Paris Prospective Study $[47,48]$ provided information that elevated fasting insulin concentration positively correlates with the risk of death from cardiovascular causes regardless of other risk factors.

\section{Treatment}

The goal of the treatment is not only to reduce insulin resistance, but also to protect pancreatic $\beta$ cells. The loss of $\beta$-cell's function is due to several factors: genetic and acquired (glucotoxicity, lipotoxicity and incretin deficiency). Modification of genetic factors may prove to be the future of medicine, while at the moment one can influence factors acquired through:

- weight loss - lifestyle change, drug therapy and bariatric surgery,

- increased physical activity,

- diet restrictions

- drugs

Studies have shown that the total weight loss increases insulin sensitivity, inhibits the progression of prediabetes to diabetes and protects pancreatic $\beta$ cells.

In the case of nutritional changes, it is important to include increased consumption of low energy density foods, individual selection of energy supply depending on age, sex and level of physical activity. The low glycemic index menu is the least stimulating diet for insulin secretion.

For physical exertion, the most recommended form is moderate exercise, carried out for at least half an hour 5 times a week, or intensive exercise carried out for at least 20 minutes 3 times a week. In addition to following a proper diet and increased physical activity, pharmacological therapy is also important. Metformin is a drug that decreases insulin resistance.

The action of this substance is pleiotropic and includes, among others:

- lowering glucose levels

- weight loss due to decreased appetite

- reduction of total cholesterol and triglycerides in serum

- an increase in insulin sensitivity of hepatocytes and myocytes and a decrease in the frequency of progression of prediabetes to type 2 diabetes

- inhibiting the formation and accumulation of end products of advanced protein glycation Metformin is the primary hypoglycemic drug that is usually introduced first in patients with type 2 diabetes and increasingly in patients with type 1 diabetes associated with overweight / obesity. It has been shown that treatment with metformin of patients with diabetes reduces, among others, risk of cardiovascular complications and overall mortality compared to other drugs such as insulin or sulfonylurea $[49,50]$. 
Treatment with metformin should be started at low doses to avoid gastrointestinal side effects (abdominal discomfort, metallic aftertaste, loose stools, nausea). However, clinical practice has shown that side effects are rare and generally transient [51].

Patients with insulin resistance are advised to gradually lose weight - by 5-10\% in each year of therapy until they reach normal weight (BMI $<25 \mathrm{~kg} / \mathrm{m} 2$ ). Most patients require a reduction in existing obesity. The optimal weight loss rate is $0.5-1 \mathrm{~kg}$ per week. It is important to change your long-term eating habits and not achieve results in a short time. Weight reduction is mainly carried out by limiting food rations, cyclical meals and daily exercise [52, 53].

Hope for better glycemic control is given by studies on the genetic reprogramming of human cells [54] and the possibility of using the batatrofin hormone [55]. It is likely that the use of this hormone once a month, and maybe even once a year, will help keep pancreatic $\beta$ cells active. This will allow you to regulate your plasma glucose levels at a level that matches daily insulin therapy.

\section{REFERENCES}

1. Grzesiuk W, Szydlarska D, Jóźwik K. Insulinooporność w endokrynopatiach. Endokrynol. Otyłość i Zaburzenia Przemiany Mater. 2008;4:38-44.

2. Drzycimska-Tatka B, Drab-Rybczyńska A, Kasprzak J. Zespół metaboliczny-epidemia XXI wieku. Hygeia Public Heal. 2011;46:423-30.

3. Matulewicz N, Karczewska-Kupczewska M. Insulinooporność a przewlekła reakcja zapalna. Postep. Hig Med Dosw. 2016;70:1245-57.

4. Wesołowski P, Wańkowicz Z. Insulinooporność - metody rozpoznawania i następstwa kliniczne. Forum Nefrol. 2011;4:313-9.

5. Jasik M, Karnafel W. Pathophysiological aspects of insulin for the cardiovascular system and blood pressure values. Prz. Kardiodiabetologinczny. 2009;4:25-9.

6. Wilczak J, Jank M. Fizjologiczne I Biochemiczne Mechanizmy Związane Z Przemianami Energetycznymi Zachodzącymi W Czasie Wysiłku Fizycznego. Kosmos. 2010;4:403-11.

7. Luiza Napiórkowska EFF. Insulin resistance and prediabetes. Postępy Nauk Med. 2017.

8. Bednarek-Tupikowska G, Matczak-Giemza M, Kubicka E, Krzyżanowska-świniarska B. Metaboliczna otyłość u osób z prawidłową masą ciała. Endokrynol. Otyłość i Zaburzenia Przemiany Mater. 2007;3:55-61.

9. Barbara Dżygadło, Celina Łepecka-Klusek BP. Wykorzystanie analizy impedancji bioelektrycznej w profilaktyce i leczeniu nadwagi i otyłości Use of bioelectrical impedance analysis in prevention and treatment of overweight and obesity. Probl Hig Epidemiol. 2012;93:274-80.

10. Kokot IMM, Pawlik-Sobecka L, Płaczkowska S, Żółcińska-Wilczyńska M, Piwowar A. The relationship between total body fat and distribution of body fat mass and markers of insulin resistance in young women with normal weight - a pilot study. Clin. Diabetol. 2016;5:41-8.

11. Yaribeygi H, Farrokhi FRR, Butler AEE, Sahebkar A. Insulin resistance: Review of the underlying molecular mechanisms. J. Cell. Physiol. 2019;234:8152-61. 
12. Gierach M, Gierach J, Junik R. Insulinooporność a choroby tarczycy. Endokrynol. Pol. 2014;65:70-6.

13. Słoma M, Szeja N. Wpływ antocyjanów na insulinooporność. Forum Zaburzeń Metab. 2018;9:175-81.

14. Stąpor N, Beń-Skowronek I. Insulin resistance in children. Pediatr. Endocrinol. Diabetes Metab. 2014;20:107-15.

15. Gutch M, Kumar S, Razi SMM, Gupta KKK, Gupta A. Assessment of insulin sensitivity/resistance. Indian J. Endocrinol. Metab. 2015;19:160-4.

16. Altuve M, Severeyn E, Wong S. Optimized fasting and OGTT-based simple surrogate methods for assessing insulin sensitivity. Diabetes Metab. Syndr. Clin. Res. Rev. 2019;13:2683-7.

17. Roden M, Petersen K, Shulman G. Insulin Resistance in Type 2 Diabetes. Textb. Diabetes. Chichester, UK: John Wiley \& Sons, Ltd. 2016:174-86.

18. Polak K, Czyzyk · A, Simoncini · T, Meczekalski $\cdot$ B. New markers of insulin resistance in polycystic ovary syndrome. J Endocrinol Invest. 2017;40:1-8.

19. Ormazabal V, Nair S, Elfeky O, Aguayo C, Salomon C, Zuñiga FA. Association between insulin resistance and the development of cardiovascular disease. Cardiovasc. Diabetol. 2018;17:1-14.

20. Warram JHH, Martin BCC, Krolewski ASS, Soeldner JSS, Kahn CRR. Slow glucose removal rate and hyperinsulinemia precede the development of type II diabetes in the offspring of diabetic parents. Ann. Intern. Med. 1990;113:909-15.

21. Hanley AJGJG, Williams K, Gonzalez C, D’Agostino RBB, Wagenknecht LEE, Stern MPP et al. Prediction of type 2 diabetes using simple measures of insulin resistance:

Combined results from the San Antonio Heart Study, the Mexico City Diabetes Study, and the Insulin Resistance Atherosclerosis Study. Diabetes. 2003;52:463-9.

22. Goedeke L, Perry RJ, Shulman GI. Emerging Pharmacological Targets for the Treatment of Nonalcoholic Fatty Liver Disease, Insulin Resistance, and Type 2 Diabetes. Annu. Rev. Pharmacol. Toxicol. 2019;59:65-87.

23. Małecki MTT. Otyłość - insulinooporność - cukrzyca typu 2. Kardiol. Pol. 2006;64:561-6.

24. LeRoith D. $\beta$-cell dysfunction and insulin resistance in type 2 diabetes: role of metabolic and genetic abnormalities. Am. J. Med. 2002;113:3-11.

25. Lillioja S, Mott DMM, Spraul M, Ferraro R, Foley JEE, Ravussin E et al. Insulin Resistance and Insulin Secretory Dysfunction as Precursors of Non-Insulin-Dependent Diabetes Mellitus: Prospective Studies of Pima Indians. N. Engl. J. Med. 1993;329:1988-92. 26. Clark A, Jones LCC, De Koning E, Hansen BCC, Matthews DRR. Decreased insulin secretion in type 2 diabetes: A problem of cellular mass or function? Diabetes. American Diabetes Association. 2001;50:S169.

27. Burghen GA, Givens JR, Kitabchi AE. Correlation of hyperandrogenism with hyperinsulinism in poly cystic ovarian disease. J. Clin. Endocrinol. Metab. 1980;50:113-6.

28. Dunaif A, Segal KR, Futterweit W, Dobrjansky A. Profound peripheral insulin resistance, independent of obesity, in polycystic ovary syndrome. Diabetes. 1989;38:1165-74. 29. Dunaif A. Insulin Resistance and the Polycystic Ovary Syndrome: Mechanism and Implications for Pathogenesis*. Endocr. Rev. 1997;18:774-800. 
30. Zeng B, Lai Z, Sun L, Zhang Z, Yang J, Li Z et al. Structural and functional profiles of the gut microbial community in polycystic ovary syndrome with insulin resistance (IRPCOS): a pilot study. Res. Microbiol. 2019;170:43-52.

31. Cheatham B, Kahn CR. Insulin action and the insulin signaling network. Endocr. Rev. 1995; 16:117-42.

32. Dunaif A, Segal KR, Shelley DR, Green G, Dobrjansky A, Licholai T. Evidence for distinctive and intrinsic defects in insulin action in polycystic ovary syndrome. Diabetes. 1992;41:1257-66.

33. Seow K-M, Juan C-C, Hsu Y-P, Hwang J-L, Huang L-W, Ho L-T. Amelioration of insulin resistance in women with PCOS via reduced insulin receptor substrate-1 Ser312 phosphorylation following laparoscopic ovarian electrocautery. Hum. Reprod. 2007;22:100310.

34. Zafar U, Khaliq S, Ahmad HU, Manzoor S, Lone KP. Metabolic syndrome: an update on diagnostic criteria, pathogenesis, and genetic links. Hormones. 2018;17:299-313.

35. Wożakowska-Kapłon B. Nowe możliwości terapii osób z zespołem metabolicznym. Folia Cardiol. 2019;14:264-71.

36. Tankó LB, Siddiq A, Lecoeur C, Larsen PJ, Christiansen C, Walley A et al. ACDC/adiponectin and PPAR- $\gamma$ gene polymorphisms: Implications for features of obesity. Obes. Res. 2005;13:2113-21.

37. Ginsberg HN. Insulin resistance and cardiovascular disease. J. Clin. Invest. 2000;106:453-8.

38. Bloomgarden ZT. Insulin Resistance, Dyslipidemia, and Cardiovascular Disease. Diabetes Care. 2007;30:2164-70.

39. Kong C, Elatrozy T, Anyaoku V, Robinson S, Richmond W, Elkeles RS. Insulin resistance, cardiovascular risk factors and ultrasonically measured early arterial disease in normotensive Type 2 diabetic subjects. Diabetes. Metab. Res. Rev. 2000;16:448-53.

40. Savaiano DA, Story JA. Cardiovascular Disease and Fiber: Is Insulin Resistance the Missing Link? Nutr. Rev. 2009;58:356-8.

41. Rader DJ. Effect of Insulin Resistance, Dyslipidemia, and Intra-abdominal Adiposity on the Development of Cardiovascular Disease and Diabetes Mellitus. Am. J. Med. 2007;120:S12-8.

42. Laakso M, Kuusisto J. Insulin resistance and hyperglycaemia in cardiovascular disease development. Nat. Rev. Endocrinol. 2014;10:293-302.

43. Reaven G. Insulin resistance and coronary heart disease in nondiabetic individuals. Arterioscler. Thromb. Vasc. Biol. 2012;32:1754-9.

44. Howard G, O'Leary DH, Zaccaro D, Haffner S, Rewers M, Hamman R et al. Insulin sensitivity and atherosclerosis. Circulation. 1996;93:1809-17.

45. Pyörälä M, Miettinen H, Laakso M, Pyörälä K. Hyperinsulinemia predicts coronary heart disease risk in healthy middle- aged men: The 22-year follow-up results of the Helsinki Policemen Study. Circulation. 1998;98:398-404.

46. Després JP, Lamarche B, Mauriège P, Cantin B, Dagenais GR, Moorjani S et al. Hyperinsulinemia as an independent risk factor for ischemic heart disease. N. Engl. J. Med. 1996;334:952-7.

47. Eschwege E, Richard JL, Thibult N, Ducimetière P, Warnet JM, Claude JR et al. 
Coronary heart disease mortality in relation with diabetes, blood glucose and plasma insulin levels. The Paris Prospective Study, ten years later. Horm. Metab. Res. Suppl. 1985;15:41-6. 48. Fontbonne AM, Eschwege EM. Insulin and Cardiovascular Disease: Paris Prospective Study. Diabetes Care. 1991;14:461-9.

49. Romańska R, Franek E. Współczesne leczenie otyłości u pacjentów z cukrzycą. Post N Med. 2017:89-94.

50. Turner R. Effect of intensive blood-glucose control with metformin on complications in overweight patients with type 2 diabetes (UKPDS 34). Lancet. 1998;352:854-65.

51. Fowler M. Leczenie cukrzycy: insulina i inkretyny. Diabetol. po Dyplomie. 2011;8:41-6.

52. Suliburska J, Kuśnierek J. Czynniki żywieniowe i pozażywieniowe w rozwoju insulinooporności. Forum Zaburzeń Metab. 2010;1:177-83.

53. Kowalska H, Lenart A, Marzec A, Kowalska J, Samborska K, Żebrowska MA. Wykorzystanie Produktów Prozdrowotnych I Suplementów Diety W Insulinoopornośći. Postępy Tech. Przetwórstwa Spożywczego. 2017;2:46-55.

54. Lee J, Sugiyama T, Liu Y, Wang J, Gu X, Lei J et al. Expansion and conversion of human pancreatic ductal cells into insulin-secreting endocrine cells. Elife. 2013. doi:10.7554/eLife.00940.

55. Zdrojewicz Z, Bugaj B, Cabała K, Pypno D, Waracki M. Nowoczesne kierunki leczenia cukrzycy. Diabetol. Klin. 2014;3:198-205. 